Article

\title{
Effect of Bee Venom and Its Fractions on the Release of Pro-Inflammatory Cytokines in PMA-Differentiated U937 Cells Co-Stimulated with LPS
}

\author{
Jonans Tusiimire ${ }^{1}$, Jennifer Wallace ${ }^{2}$, Nicola Woods ${ }^{1}$, Mark J. Dufton ${ }^{2}$, John A. Parkinson ${ }^{2}$, \\ Grainne Abbott ${ }^{1}$, Carol J. Clements ${ }^{1}$, Louise Young ${ }^{1}$, Jin Kyu Park ${ }^{3}$, Jong Woon Jeon ${ }^{3}$, \\ Valerie A. Ferro ${ }^{1}$ and David G. Watson ${ }^{1, *}$
}

1 Strathclyde Institute of Pharmacy and Biomedical Sciences, University of Strathclyde, 161 Cathedral Street, Glasgow G4 0RE, U.K.; jonans.tusiimire@strath.ac.uk (J.T.); nicola.woods@strath.ac.uk (N.W.); grainne.abbott@strath.ac.uk (G.A.); c.j.clements@strath.ac.uk (C.J.C.); Louise.c.young@strath.ac.uk (L.Y.); v.a.ferro@strath.ac.uk (V.A.F.)

2 WestCHEM Department of Pure and Applied Chemistry, University of Strathclyde, 295 Cathedral Street, Glasgow G1 1XL, U.K.; jennifer.wallace.101@strath.ac.uk (J.W.); mark.dufton@strath.ac.uk (M.J.D.); john.parkinson@strath.ac.uk (J.A.P.)

3 \#204, Beesen Co. Ltd., Bio Venture Town, Yuseong Daero 1662, 34054 Dae Jeon, Korea; jkypark@live.co.kr (J.K.P.); confessor@hanmail.net (J.W.J.)

* Correspondence: d.g.watson@strath.ac.uk; Tel.: +44-141-548-2651; Fax: +44-141-552-6443

Academic Editor: Diane M. Harper

Received: 2 March 2016; Accepted: 13 April 2016; Published: 19 April 2016

\begin{abstract}
The venom of Apis mellifera (honey bee) has been reported to play a role in immunotherapy, but existing evidence to support its immuno-modulatory claims is insufficient. Four fractions from whole bee venom (BV) were separated using medium pressure liquid chromatography. Their ability to induce the production of cytokines TNF $\alpha$, IL-1 $\beta$ and IL-6 in phorbol-12-myristate-13-acetate (PMA)-treated U937 cells was assessed. The levels of the three cytokines produced by stimulation with the four fractions and crude BV without LPS were not significantly different from negative control values. However, co-stimulation of the cells with LPS and Fraction 4 (F-4) induced a 1.6-fold increase in TNF- $\alpha$ level $(p<0.05)$ compared to LPS alone. Likewise, LPS-induced IL-1 $\beta$ production was significantly synergised in the presence of F-1 (nine-fold), F-2 (six-fold), F-3 (four-fold) and F-4 (two-fold) fractions, but was only slightly enhanced with crude BV (1.5-fold) relative to LPS. Furthermore, the LPS-stimulated production of IL-6 was not significantly increased in cells co-treated with F-2 and F-3, but the organic fraction (F-4) showed an inhibitory effect $(p<0.05)$ on IL-6 production. The latter was elucidated by NMR spectroscopy and found to contain(Z)-9-eicosen-1-ol. The effects observed with the purified BV fractions were more marked than those obtained with the crude sample.
\end{abstract}

Keywords: bee venom; pro-inflammatory cytokines; LPS stimulation; U937 cells; PMA differentiated; ELISA; (Z)-9-eicosen-1-ol; Apis mellifera

\section{Introduction}

Bee venom (BV) is mainly used as a defence tool by the honey bee, and its primary function is to inflict pain on any intruders into the hive [1]. Despite its pain-causing effects, the main reported human administration uses relate to pain relief in conditions, such as arthritis and rheumatism [2,3], tendonitis, multiple sclerosis, wounds and gout [4-6]. The chemical composition of BV is complex, but the primary ingredients are bioactive peptides, proteins and several other biomolecules [6-10]. 
The principal component is a 26-amino acid haemolytic peptide, melittin, which accounts for about $50 \%-60 \%$ of the venom by dry weight and is responsible for most of the observed effects $[9,11,12]$.

BV components have been reported to possess various and, sometimes, conflicting immune-related effects. Available evidence suggests that apamin [13], histamine [14], mast cell degranulating (MCD) peptide $[15,16]$ and phospholipase $\mathrm{A}_{2}\left(\mathrm{PLA}_{2}\right)$ [17] significantly increase the inflammatory response. The small neurotoxic peptide apamin (MW $2.0 \mathrm{kDa}$ ) is a $\mathrm{Ca}^{2+}$-activated $\mathrm{K}^{+}$-channel blocker, which has been reported to increase murine T-cell proliferation [13]. However, it has also been reported to inhibit histamine release in lung tissues, suggesting that it could decrease allergic airway inflammation through mast cell stabilisation [18]. Park et al. (2004) also demonstrated that histamine increased the production of IL-6 in nasal fibroblasts and induced nuclear factor kappa B (NF-KB) [14], a transcriptional factor for many pro-inflammatory genes [19]. On the other hand, MCD peptide was reported to inhibit histamine release from mast cells [15] by binding, in a dose-related manner, to mast cell receptors, thereby partially inhibiting $\operatorname{IgE}$ binding to these receptors [20]. Similarly, PLA 2 was shown to activate T-cells via its action on phospho-diacylglycerides to form small neoantigenic factors in vivo, in a process dependent on antigen presentation by CD1a proteins [17].

Conversely, some components of BV have been reported to possess anti-inflammatory actions. For instance, the basic polypeptide adolapin (MW $11.5 \mathrm{kDa}$ ) was reported to possess anti-inflammatory and analgesic activities in carrageenan-, prostaglandin- and adjuvant-induced rat oedema and adjuvant polyarthritis [21]. These effects were attributed to the inhibition of prostaglandin synthesis, via cyclooxygenase inhibition, as well as through central mechanisms [21]. Adolapin was also shown to inhibit the activity of BV PLA 2 and human lipoxygenase from platelets and possessed antipyretic effects [22].

Past reports on immuno-modulating effects of the main bee venom peptide melittin are rather contradictory. For instance, whereas Bramwell et al. (2003) reported dose-dependent mucosal adjuvant action of intranasal melittin co-administered with tetanus and diphtheria toxoids in mice [23], a number of other studies have reported its "neutralising" effects on LPS in murine macrophage cell lines $[24,25]$. The adjuvant effects of melittin were linked to its enhancement of vaccine absorption across the mucosal lining, which led to higher antibody (IgG) titres than those of either component alone [23]. On the other hand, its antagonistic effects on LPS were linked to inhibition of NF-kB binding to DNA [24] and phosphorylation of IKB kinase [25], respectively. In addition, treatment of LPS-stimulated BV2 immortalized murine microglial cells with BV or melittin, decreased the expression of pro-inflammatory cytokines (IL-1 $\beta$, IL- 6 and TNF- $\alpha$ ) and inhibited inducible nitric oxide synthase (iNOS) production and nitric oxide (NO) expression, as was the expression of cyclooxygenase-2 (COX-2) and prostaglandin $\mathrm{E}_{2}\left(\mathrm{PGE}_{2}\right)$ production [26,27]. These anti-inflammatory effects were linked mainly to the leucine zipper sequence in melittin, which contains two leucine residues, since Leu-Ala substitution in this sequence progressively reduced this neutralising effect [27]. Jang et al. (2005) also reported anti-inflammatory effects of BV in RAW 264.7 macrophages that were attributed to a downregulation of iNOS, COX-2, NF- $\mathrm{kB}$ and mitogen-activated protein kinases (MAPKs) [28]. In addition, Park et al. (2004) also reported that BV and melittin decreased carrageenan-induced oedema and adjuvant-induced arthritis in rat models consistent with their inhibitory effects on LPS-induced expression of COX-2, cytosolic PLA ${ }_{2}$ and iNOS and on the generation of $\mathrm{PGE}_{2}$ and $\mathrm{NO}$ [24]. BV and melittin also prevented LPS-induced transcriptional and DNA binding activity of NF- $\mathrm{kB}$ via inhibition of IKB release [2].

Since upregulation of most pro-inflammatory genes (e.g., cytokines and chemokines) relies on activation of NF-KB [19], inactivation of the latter by BV or its components would be a key mechanism for exerting anti-inflammatory effects [29]. However, in a previous study, no significant inactivation of IL-1 $\beta$-induced NF- $\mathrm{KB}$ was observed in fibroblast-like synoviocytes from rheumatoid arthritis patients, as well as in dermal fibroblasts and red blood cells from healthy volunteers, after treatment with BV and melittin [30]. In addition, there was no effect on the phosphorylation or degradation of IKB, and even at high concentrations, BV and melittin had no effect on NF-kB-p50-DNA interactions. Instead, 
significant increases in mRNA levels of several pro-inflammatory genes (including COX-2, IL-1 $\beta$, TNF- $\alpha$ ) and large quantities of oxygen radicals were observed following exposure to BV or melittin [30]. This suggested that melittin alone and BV as a whole are pro- rather than anti-inflammatory.

In the current study, the effects of BV and its fractions on the production of cytokines TNF- $\alpha$, IL-1 $\beta$ and IL-6 were investigated in PMA-treated U937 cells. The latter belong to a monocytic differentiation lineage derived from malignant cells of a patient with generalised histiocytic lymphoma [31], and their differentiation with PMA, a potent tumour promoting agent [32], is known to impart functional properties typical of macrophages [32-34]. The presence of synergy between BV and LPS, a standard antigen, in inducing the production of the pro-inflammatory mediators would suggest the potential application of BV as a source of immuno-modulating agents for use as vaccine adjuvants.

\section{Materials and Methods}

\subsection{Cell Culture}

U937 cell cultures (obtained from ECACC, Porton Down, Salisbury, UK) were seeded at $3 \times 10^{5}$ cells $/ \mathrm{mL}$ in RPMI-1640 (Lonza, Verviers, Belgium) supplemented with $2 \mathrm{mM}$ L-glutamine (Life Tech, Paisley, UK), $100 \mathrm{IU} / 100 \mu \mathrm{g} / \mathrm{mL}$ penicillin/streptomycin (Life Tech, Paisley, UK) and 10\% (v/v) foetal bovine serum (FBS) (Sigma-Aldrich, Dorset, UK). Cells were subcultured every 2-4 days and maintained at $37^{\circ} \mathrm{C}$ in a humidified atmosphere of $5 \% \mathrm{CO}_{2}$.

\subsection{Test Sample Isolation, Preparation and Analysis}

Crude BV (supplied lyophilized by Beesen Co. Ltd., Dae Jeon, Korea) was prepared for bioassay by dissolving $10 \mathrm{mg}$ in $1 \mathrm{~mL}$ of dimethyl sulphoxide (DMSO, Sigma-Aldrich) followed by filtration through a $0.2-\mu \mathrm{m}$ filter (Millex ${ }^{\circledR}$, Sigma-Aldrich). The venom fractions F-1-F-4 were isolated from $800 \mathrm{mg}$ of crude BV by reversed phase medium pressure liquid chromatography (MPLC) on a Reveleris ${ }^{\circledR} \mathrm{iES}$ flash chromatography system (Grace Davison Discovery Sciences, Carnforth, UK) with dual UV $(\lambda=220 / 280 \mathrm{~nm})$ and evaporative light scattering (ELSD) detection. The sample was mixed with $3 \mathrm{~g}$ of Celite ${ }^{\circledR}$ before loading it into a dry-loading cartridge. The column used was an Easyvarioflash D24 cartridge (VWR International, Lutterworth, UK) packed with ca. $13 \mathrm{~g}$ of Polymeric Retain PEP for SPE (Thermo Scientific, Paisley, U.K.), as previously described [35]. Fraction F-1 was eluted with $100 \%$ water and F-4 with 100\% acetonitrile (Sigma-Aldrich), both solvents being of HPLC grade. Fractions F-2 and F-3 were eluted in water/acetonitrile mixtures of $80 / 20 \%$ and $50 / 50 \%$, respectively. The resulting purified fractions were freeze-dried and stored at $-30{ }^{\circ} \mathrm{C}$ until required for the assay. Samples for bioassays were reconstituted at $10 \mathrm{mg} / \mathrm{mL}$ in DMSO. Liquid chromatography-mass spectrometry (LC-MS) analysis of the freeze-dried fractions was carried out. The samples were reconstituted in water (F-1, F-2 and F-3) or acetonitrile:water (1:1) (F-4) to achieve concentrations of $0.1 \mathrm{mg} / \mathrm{mL}$ in each case, and $10-\mu \mathrm{L}$ aliquots were injected into a Finnigan Surveyor HPLC system interfaced to an Orbitrap Mass Spectrometer (Thermo Fisher Scientific, Bremen, Germany). All of the samples were analysed using an ACE 3 C18 column $(150 \times 3.0 \mathrm{~mm}, 3 \mu \mathrm{m}$ particle size) supplied by Hichrom Ltd. (Reading, UK). The mobile phase consisted of $0.1 \%$ formic acid in water (A) and $0.1 \%$ formic acid in acetonitrile (B) at a flow rate of $0.3 \mathrm{~mL} / \mathrm{min}$. The gradient used for F-1 to F-3 was $20 \%-70 \% \mathrm{~B}$ from $0-10 \mathrm{~min}, 6 \mathrm{~min}$ hold at $70 \% \mathrm{~B}$, then return to $20 \% \mathrm{~B}$ over $4 \mathrm{~min}$, followed by $5 \mathrm{~min}$ re-equilibration. In the case of F-4, an initial 5-min isocratic profile at $50 \% \mathrm{~B}$ was followed by a 1-min ramp to $95 \% \mathrm{~B}$, held there for $8 \mathrm{~min}$, before a 1-min return to $50 \%$ B and re-equilibration for $4 \mathrm{~min}$. Full scan spectra were obtained within $m / z$ 100-2000 in the positive ESI mode for all samples, except F-4, which was detected in the $m / z$ range 200-1200 in the negative ESI mode. For MS/MS of F-4, collision-induced dissociation (CID) of the $[\mathrm{M}-\mathrm{H}]^{-}$parental ion was carried out at a normalised collisional energy of $35.0 \mathrm{~V}$, and the product ion scan was made in the $m / z$ rage of 200-700, also in the negative ESI mode. The spray needle voltages were set at 4.5 and $-3.5 \mathrm{kV}$ in positive and negative ESI modes, respectively. The sheath and auxiliary gas flow rates were 
50 and 15 arbitrary units, respectively, while ion transfer capillary temperature was set at $275^{\circ} \mathrm{C}$. All data were collected and processed using XCalibur software (version 2.1.0, Thermo Fisher Scientific, Bremen, Germany).

\subsection{Cytotoxicity Assay}

U937 cells were seeded at $2.25 \times 10^{4}$ cells/well in 96-well plates (Corning ${ }^{\circledR}$, Sigma-Aldrich) and incubated in the presence and absence of $\mathrm{BV}$ or its fractions at final concentrations ranging from $100 \mu \mathrm{g} / \mathrm{mL}-3 \mathrm{ng} / \mathrm{mL}(n=3)$. Triton $\mathrm{X}$ at $1 \%(v / v)$ served as a positive control. The plate was then incubated at $37^{\circ} \mathrm{C}$ and $5 \% \mathrm{CO}_{2}$ in a humidified atmosphere for $48 \mathrm{~h}$. After incubation, Alamar ${ }^{\circledR}$ Blue (AbD Serotec ${ }^{\circledR}$, Kidlington, U.K.) was added at a final concentration of $10 \%$ in a total assay volume of $100 \mu \mathrm{L}$ per well and the plate incubated for a further $6 \mathrm{~h}$. Fluorescence readings of the plate were taken using a Perkin Elmer Wallac Victor ${ }^{2} 1420$ Multilabel Counter ( $\left.\lambda_{\mathrm{Ex} / \mathrm{EM}}: 560 / 590 \mathrm{~nm}\right)$. All readings were corrected for background by subtracting the mean fluorescence of the Triton $X$ wells. Cell viability was then calculated for each well as a percentage of fluorescence readings in the presence of test sample relative to the mean value of the negative controls. The resulting data were analysed with GraphPad Prism for Windows (version 4.03, GraphPad Software, San Diego, CA, USA, www.graphpad.com) to obtain dose-response curves for each sample and their corresponding mean inhibitory concentration $\left(\mathrm{IC}_{50}\right)$ values.

\subsection{Induction of Cell Differentiation}

U937 cells were seeded at $4.5 \times 10^{4}$ cells/well in a volume of $450 \mu \mathrm{L}$ in 24-well tissue culture plates (Corning ${ }^{\circledR}$, Sigma-Aldrich) $(n=3)$ in media containing 60 ng/mL PMA (Sigma-Aldrich). A control well containing cells in media without PMA was also included. The cells were then incubated in a humidified atmosphere at $37^{\circ} \mathrm{C}$ and $5 \% \mathrm{CO}_{2}$ for $48 \mathrm{~h}$. Micrographs of the cells were taken after 24 and $48 \mathrm{~h}$ for evidence of differentiation.

\subsection{Stimulation of Cytokine Release}

After $48 \mathrm{~h}$ of differentiation, the media were aspirated and replaced with fresh media, without PMA, and the cells incubated for a further $24 \mathrm{~h}$. At this point, samples of BV or fractions, with or without Escherichia coli (E. coli) LPS (Sigma-Aldrich), were then added from a separate sample dilution plate prepared using $10 \mathrm{mg} / \mathrm{mL}$ stock solutions (Table S1 in the Supplementary Materials). The final concentrations of the samples on the cell culture plate were $100 \mu \mathrm{g} / \mathrm{mL}$ (F-1 and F-2), $12 \mu \mathrm{g} / \mathrm{mL}$ (F-3 and BV) and $120 \mu \mathrm{g} / \mathrm{mL}$ (F-4), respectively. The final LPS concentration in the LPS-containing samples was $1 \mu \mathrm{g} / \mathrm{mL}$.

\subsection{Assessment of Cytokine Release}

Three ELISA kits from R\&D Systems (Abingdon, U.K.) were used to assess the release of interleukin (IL)-1 $\beta / \mathrm{IL}-1 \mathrm{~F}-2$, IL-6 and tumour necrosis factor (TNF)- $\alpha$ from LPS-stimulated and non-stimulated U937 cells. The ELISA assay was carried out according to the kit manufacturer's instructions, except that the colour substrate used (3,3'5,5'-tetramethylbenzidine, TMB) was from Sigma-Aldrich (Dorset, U.K.) and came as ready for use. The reaction was stopped with 2 N sulphuric acid $\left(\mathrm{H}_{2} \mathrm{SO}_{4}\right)$ and the plate was read immediately at a 450-nm wavelength using a SpectraMax Pro 5 (Wokingham, U.K.) with wavelength correction by subtracting readings taken at $570 \mathrm{~nm}$.

\subsection{Data Analysis}

Standard calibration curves were plotted by fitting the optical density data of TNF- $\alpha$, IL- $1 \beta$ and IL-6 to 4-parameter logistic (4-PL) regression curves (Table S2 and Figures S1-S9 in the Supplementary 
Materials). Each of these standards was prepared in duplicate at each of the concentrations in the ranges recommended by the manufacturer. The 4-PL regression equation is given by:

$$
y=d+\frac{a-d}{1+\left(\frac{x}{c}\right)^{b}}
$$

where $y$ is the response value (i.e., measured optical density), $x$ is the concentration (in pg/mL) and $a$, $b, c$ and $d$ are constants. The regression analysis also computes the $R^{2}$ value, which gives an indication of how best the fitted curve agrees with the data. From Equation (1), the unknown concentration, $x$, of a sample of optical density, $y$, can be calculated according to:

$$
x=c\left(\frac{a-d}{y-d}-1\right)^{\frac{1}{b}}
$$

Using Equation (2), the concentrations of TNF- $\alpha$, IL-1 $\beta$ and IL-6 induced by each of the samples assayed (with and without LPS) were calculated and expressed as ratios of the mean cytokine level induced by LPS (positive control), assayed in triplicate $(n=3)$. The resulting data were then analysed with GraphPad Prism to obtain bar graphs whose statistical significances were tested at the $95 \%$ confidence level $(\mathrm{CI})$ relative to the mean positive control ratio of 1.0.

\subsection{NMR Spectroscopy}

NMR spectroscopy was carried out on $7.4 \mathrm{mg}$ of BV fraction F-4 dissolved in $600 \mu \mathrm{L}$ DMSO- $d_{6}$. NMR data were acquired with a Bruker AVANCE II ${ }^{+}$NMR spectrometer (Bruker Biospin GmbH, Rheinstetten, Germany) equipped with a $14.1 \mathrm{~T}^{\text {Ultrashield }}{ }^{\mathrm{TM}}$ superconducting magnet operating at a ${ }^{1} \mathrm{H}$ resonance frequency of $600.13 \mathrm{MHz}$ under TopSpin (version 2.1, Bruker Biospin GmbH, Rheinstetten, Germany) running in a Microsoft Windows environment. All data were acquired using a BBO-z-atm probe head operating at ambient temperature $(298 \mathrm{~K})$ regulated by means of a BCU-05 chiller unit.

1D ${ }^{1} \mathrm{H}-\mathrm{NMR}$ spectra were acquired with 16 transients over a frequency width of $7.2 \mathrm{kHz}$ $(12.0 \mathrm{ppm})$ centred at a frequency offset of $5.0 \mathrm{ppm}$ into $32 \mathrm{~K}$ data points for an acquisition time of $2.27 \mathrm{~s}$ using a 30-degree radio frequency (r.f.) pulse and a recycle delay of $2.0 \mathrm{~s}$.

$1 \mathrm{D}{ }^{13} \mathrm{C}-\left\{{ }^{1} \mathrm{H}\right\}$ NMR spectra were acquired with 1024 transients over a frequency width of $33.33 \mathrm{kHz}(220.8 \mathrm{ppm})$ centred at a frequency offset of $100.0 \mathrm{ppm}$ into $32 \mathrm{~K}$ data points for an acquisition time of $491.5 \mathrm{~ms}$ using a 30-degree r.f. pulse with continuous composite pulse decoupling applied at the ${ }^{1} \mathrm{H}$ resonance frequency and using a recycle delay of $0.7 \mathrm{~s}$.

Complete details for all NMR experimental conditions can be found in the Supporting Information.

\section{Results}

\subsection{Composition of Fractions 1-4 from MPLC}

From LC-MS analysis, the fractions were revealed to contain mixed components in F-1 and F-2, while F-3 and F-4 both contained largely single components. The major constituents of F-1 were putatively identified to be histamine, proline, noradrenaline, 5-aminovaleric acid, cellobiose and arginine (Figure S10). Fraction F-2 contained mainly PLA 2 , as well as varying amounts of apamin, secapin and MCD peptide (Figure S11). On the other hand, melittin was the principal component of F-3 (96\% purity) (Figure S12), while the organic fraction, F-4, mainly contained a new compound identified through NMR analysis as (Z)-9-eicosen-1-ol and trace levels of an unidentified phospholipid. The LC-MS did not detect (Z)-9-eicosen-1-ol due to its absolute lack of ionisation in both positive and negative ESI modes, but instead detected the trace phospholipid impurity, undetected by NMR at its concentration in the fraction (Figure S13). 


\subsection{Cytotoxicity of BV Fractions against U937 Cells}

Cytotoxicity studies were carried out $(n=3)$ to obtain $\mathrm{IC}_{50}$ values (Figure 1$)$. Samples F-1 and $\mathrm{F}-2$ gave $\mathrm{IC}_{50}$ of greater than $100 \mu \mathrm{g} / \mathrm{mL}$. In contrast, $\mathrm{F}-3$ gave the lowest $\mathrm{IC}_{50}$ value at $5.4 \mu \mathrm{g} / \mathrm{mL}$ (or $1.9 \mu \mathrm{M}$ ). The $\mathrm{IC}_{50}$ value of F-4 was $68.8 \mu \mathrm{g} / \mathrm{mL}$. Micrographs of the cells taken after 24 and $48 \mathrm{~h}$ confirmed the assay results obtained with the Alamar ${ }^{\circledR}$ Blue assay (Figure 2). These micrographs also revealed significant microscopic differences in the appearance of cells treated with F-3 and F-4 even in wells where Alamar ${ }^{\circledR}$ Blue readings were comparable. Unlike the necrosis caused by melittin, which revealed the cells to have burst to release their protoplasm, non-viable F-4-treated cells appeared to have an intact cell outline, implying that the mechanism by which the lipid exerts its cytotoxic effect on U937 cells may be different from that of melittin, which acts through cell lysis [36].
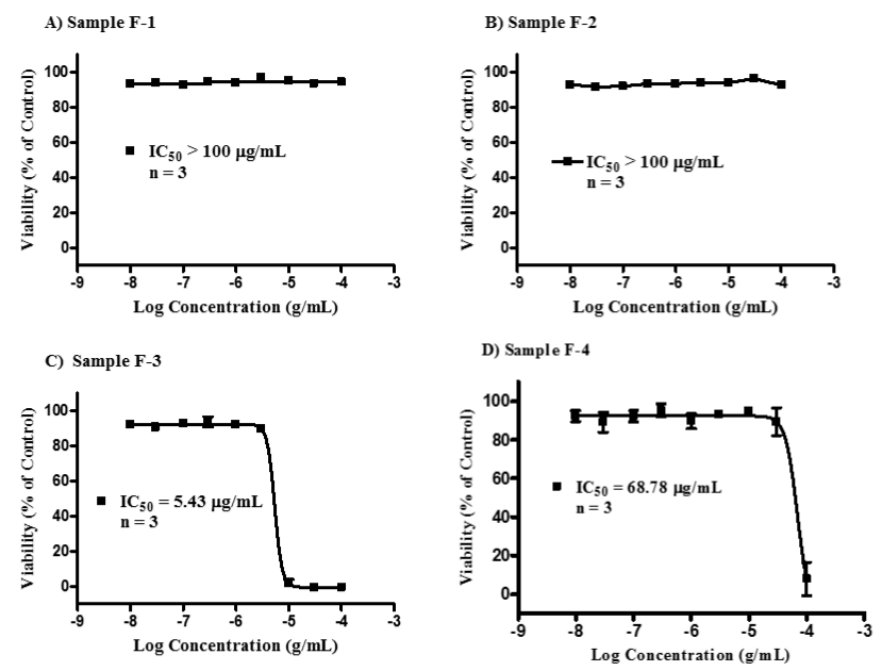

Figure 1. Cytotoxicity of the bee venom sample fractions F-1-F-4 against U937 cells. Fraction samples F-1 (A) and F-2 (B) were non-cytotoxic, each with an $\mathrm{IC}_{50}$ value $>100 \mu \mathrm{g} / \mathrm{mL}$. Fraction sample F-3 (C, melittin) was the most cytotoxic with an $\mathrm{IC}_{50}$ of $5.43(95 \% \mathrm{CI} 4.43-6.66) \mu \mathrm{g} / \mathrm{mL}$, while fraction sample F-4 (D, lipid) had an $\mathrm{IC}_{50}$ value of $68.78 \mu \mathrm{g} / \mathrm{mL}$.

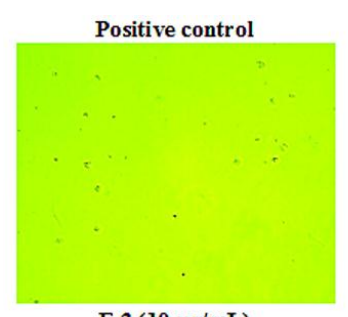

$\mathrm{F}-3(10 \mu \mathrm{g} / \mathrm{mL})$

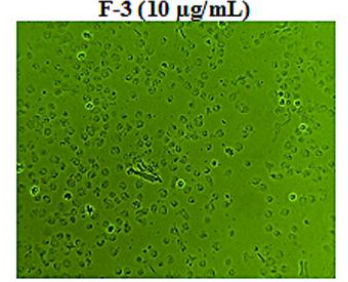

Negative control

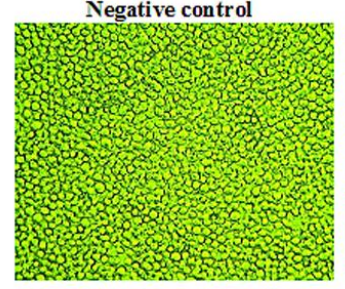

$\mathrm{F}-3(3 \mu \mathrm{g} / \mathrm{mL})$

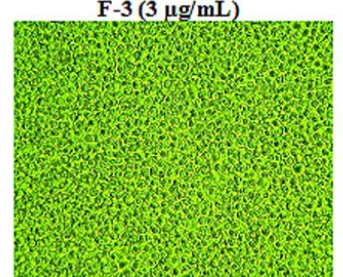

F-1 $(100 \mu \mathrm{g} / \mathrm{mL})$

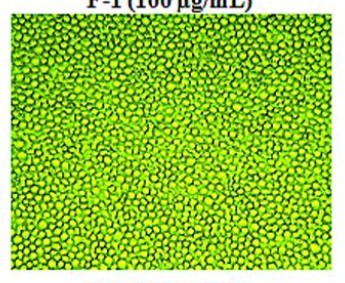

F-4 $(100 \mu \mathrm{g} / \mathrm{mL})$

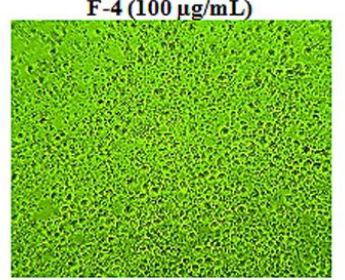

F-2 $(100 \mu \mathrm{g} / \mathrm{mL})$

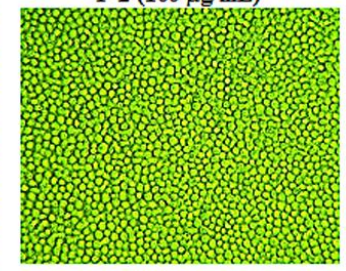

F-4 $(30 \mu \mathrm{g} / \mathrm{mL})$

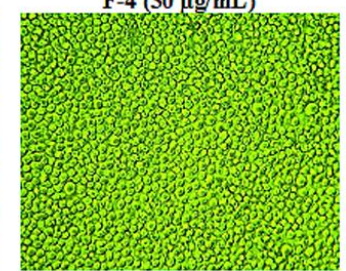

Figure 2. Cytotoxic effects of bee venom fractions on U937 cells. Fractions F-1 and F-2 were non-cytotoxic at the highest concentration of $100 \mu \mathrm{g} / \mathrm{mL}$ used, while F-3 was the most cytotoxic on the cells, as necrotic effects were observed even at $10 \mu \mathrm{g} / \mathrm{mL}\left(\mathrm{IC}_{50} 5.4 \mu \mathrm{g} / \mathrm{mL}\right)$. On the other hand, F-4 was cytotoxic above $30 \mu \mathrm{g} / \mathrm{mL}$ with an $\mathrm{IC}_{50}$ of $68.8 \mu \mathrm{g} / \mathrm{mL}(n=3)$. (Magnification $\left.=\times 100\right)$. 


\subsection{Selection of $B V$ and Fraction Concentrations for the Assay}

ELISAs were carried out in order to determine the effect of the fractions on PMA-differentiated cells with respect to the production of three inflammatory mediators TNF- $\alpha$, IL- $1 \beta$ and IL- 6 . Since the investigation of immuno-modulatory effects had to be conducted using concentrations of the fractions where the cells remained viable, concentrations were selected for each fraction that were below their respective $\mathrm{IC}_{50}$ values. Specifically, the highest final concentration of the fraction at which no toxicity was observed on the cells was used. Thus, F-1 and F-2 were each assayed at $100 \mu \mathrm{g} / \mathrm{mL}, \mathrm{F}-3$ and BV at $3 \mu \mathrm{g} / \mathrm{mL}$, while F-4 was assayed at $30 \mu \mathrm{g} / \mathrm{mL}$ (Table S3 in the Supplementary Materials). The mean viability $(n=3)$ of the cells at the concentrations selected for each of the fractions used for the assay were F-1 (93\%), F-2 (94\%) and F-3 and F-4 (90\% each), respectively, relative to the media control.

\subsection{Effect of PMA on the U937 Cells}

After the cells had been incubated in the presence of PMA, they were observed microscopically at 24 and $48 \mathrm{~h}$ for the presence of features that confirmed whether or not they had differentiated [37]. Micrographs were also taken of the treated cells and compared to those of U937 cells in control wells (absence of PMA) on the same plate (Figure 3), which confirmed the morphological changes expected.

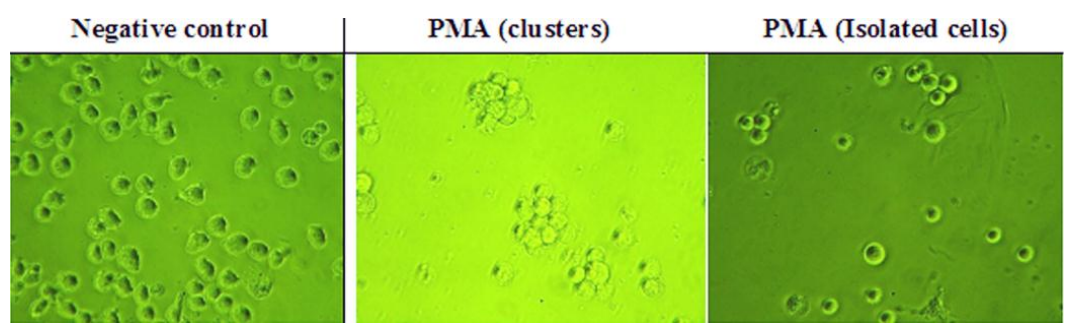

Figure 3. Effect of phorbol-12-myristate-13-acetate (PMA) on U937 cells. PMA was added to the cells at $60 \mathrm{ng} / \mathrm{mL}(n=3)$. (Magnification $=\times 400)$.

\subsection{Effect on TNF- $\alpha$ Production}

The BV fractions on their own did not induce significant TNF- $\alpha$ production in PMA-differentiated U937 cells relative to the negative control (culture media). However, when used in combination with LPS, there was a noticeable enhancement (ratio >1.0) in the amount of TNF- $\alpha$ produced compared to LPS alone. This was statistically significant $(p<0.05)$ only with F-4, which produced a 1.6-fold increase in TNF- $\alpha$ release from the cells (Figure 4 ).

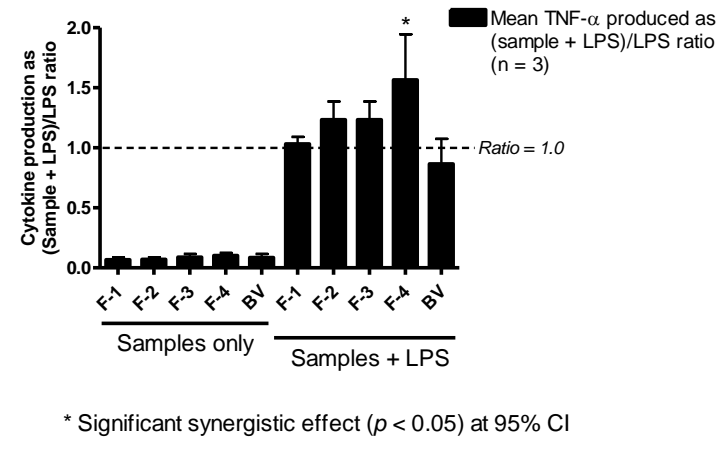

Figure 4. Effect of bee venom and its fractions of TNF- $\alpha$ production in PMA-differentiated U937 cells. All five samples tested produced slightly more than background levels of TNF- $\alpha$, but not significantly different from those of the negative control (media). The level of TNF- $\alpha$ was significantly higher in fractions co-stimulated with F-4 and LPS compared to LPS, but the other fractions did not show any significant changes in the levels of the cytokine $(n=3)$. 


\subsection{Effect on IL-1ß Production}

The enhancement of IL-1 $\beta / \mathrm{IL}-1 \mathrm{~F} 2$ by BV fractions in LPS co-stimulated U937 cells was much more pronounced than that observed with TNF- $\alpha$. Fractions F-2 and F-3 greatly enhanced IL-1 $\beta /$ IL-1F2 release in the cells by approximately nine- and six-fold, respectively. Additionally, F-1 (four-fold), F-4 (three-fold) and whole BV (two-fold) also enhanced the release of this cytokine with LPS co-stimulation, although the increase obtained with BV was not statistically significant (Figure 5). As can be seen from Figure 5, the fractions on their own did not induce any significant level of cytokine release.

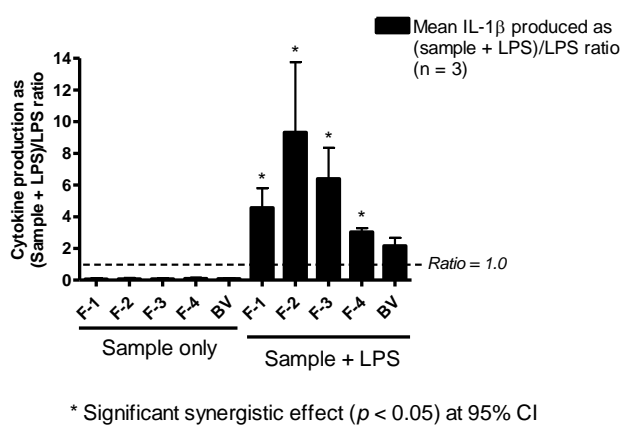

Figure 5. Effect of bee venom and its fractions of IL-1 $\beta /$ IL-1F2 production in PMA-differentiated U937 cells. All five been venom (BV) fractions tested produced only background levels of IL-1 $\beta /$ IL-1F2 when used alone. In the presence of LPS, there was significant synergy, especially with F-2 and F-3, which resulted in a nine- and six-fold increase in the production of the cytokine, respectively. Significant synergy was also observed with F-1 (four-fold) and F-4 (three-fold), but not with BV despite a two-fold increase in the latter $(n=3)$.

\subsection{Effect on IL-6 Production}

As with TNF- $\alpha$ and IL-1 $\beta$ production, the amount of IL- 6 produced by the cells in the presence of BV fractions alone was undetectable (F-1-F-3) or not significantly different from levels observed in negative controls (F-4 and BV). Yet, when the same fractions were incubated together with LPS, the amount of IL- 6 produced by the cells was raised, compared to that of stimulation with LPS alone, by $20 \%, 40 \%, 30 \%$ and 30\% with F-1, F-2, F-3 and BV, respectively; although these were not significantly different from positive control values. Surprisingly, and contrary to observations with TNF- $\alpha$ and IL-1 $\beta$, F-4 significantly decreased the amount of IL-6 released with LPS co-stimulation in the PMA-differentiated U937 cells by about 50\% (Figure 6).

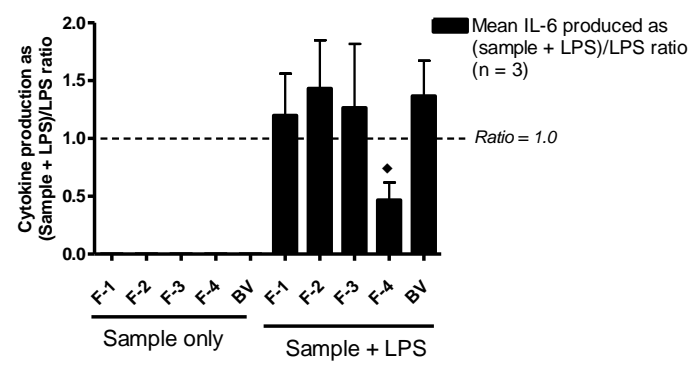

- Significant antagonistic effect $(p<0.05)$ at $95 \% \mathrm{Cl}$

Figure 6. Effect of BV and its fractions with and without LPS on IL-6 production in PMA-differentiated U937 cells. The level of IL-6 produced by BV fractions alone was undetectable. However, in combination with LPS, Fractions F-1-F-3 and BV enhanced the level of cytokine produced by LPS though not significantly. Interestingly, F-4 significantly inhibited cytokine production by about $50 \%$ of the mean positive control (LPS) value $(n=3)$. 


\subsection{Identification of Active Compound in BV Fraction F-4}

Given its unusual effect on TNF- $\alpha$ and IL-6 release in PMA-differentiated U937 cells, we sought to identify the component present in F-4 by NMR spectroscopy. The one-dimensional (1D) ${ }^{1} \mathrm{H}-\mathrm{NMR}$ spectrum of F-4 (acquired at $298 \mathrm{~K}$ in DMSO- $d_{6}$; Figure S14) gave 10 distinguishable signals with chemical shifts and integrals as detailed in Table 1 . Signal A, which corresponded to a ${ }^{1} \mathrm{H}$ chemical shift associated with a proton attached to an $\mathrm{sp}^{2}$-hybridized carbon centre (alkene), integrated to two proton equivalents. Multiplicity-edited 2D $\left[{ }^{1} \mathrm{H},{ }^{13} \mathrm{C}\right] \mathrm{HSQC}-\mathrm{NMR}$ data revealed that the signal was associated with a methine $(\mathrm{CH})$ group, allowing the conclusion to be drawn that the molecule was likely to be a structure with close to two-fold symmetry about a double bond. The signal envelope designated $\mathrm{H}$ integrated to twenty two proton equivalents and suggested the presence of long chains of methylene groups typical of a lipid.

Table 1. Data arising from the $1 \mathrm{D}^{1} \mathrm{H}-\mathrm{NMR}$ spectrum of the lipid component. Reference to the "link to ${ }^{13} \mathrm{C}^{\prime \prime}$ arises from analysis of the $2 \mathrm{D}\left[{ }^{1} \mathrm{H},{ }^{13} \mathrm{C}\right]$ HSQC-NMR spectrum that reveals ${ }^{1} J_{\mathrm{HC}}$ correlations where labels a-q correspond to the ${ }^{13} \mathrm{C}$ resonances shown in (Figure S12).

\begin{tabular}{|c|c|c|c|c|c|c|}
\hline Label & $\delta(\mathrm{ppm})$ & Integral & Type & Multiplicity & Link to ${ }^{13} \mathrm{C}$ & Proposal \\
\hline A & 5.32 & 2 & Alkene CH & Second order & a & $\begin{array}{c}\text { Symmetric } \\
\text { Alkene }\end{array}$ \\
\hline B & 4.30 & 1 & $-\mathrm{OH}$ & $\mathrm{t}$ & - & $-\mathrm{CH}_{2}-\mathrm{OH}$ \\
\hline $\mathrm{C}$ & 3.36 & 2 & $-\mathrm{CH}_{2}^{-}$ & $\mathrm{dt}$ & $b$ & \\
\hline $\mathrm{D}$ & 3.32 & 1.7 & $\mathrm{H}_{2} \mathrm{O}$ & $\mathrm{s}$ & - & $\begin{array}{l}\text { Water in } \\
\text { DMSO }\end{array}$ \\
\hline $\mathrm{E}$ & 1.98 & 4 & $-\mathrm{CH}_{2-}$ & $\mathrm{q}$ & $\mathrm{m}$ & \\
\hline $\mathrm{F}$ & 1.39 & 2 & $-\mathrm{CH}_{2-}^{-}$ & pentet & c & \\
\hline G & 1.29 & 4 & $-\mathrm{CH}_{2}^{-}$ & $q$ & $\mathrm{f}$ & \\
\hline $\mathrm{H}$ & 1.24 & 22 & $-\mathrm{CH}_{2-}^{-}$ & - & $\mathrm{d}, \mathrm{e}, \mathrm{g}, \mathrm{h}, \mathrm{i}, \mathrm{j}, \mathrm{k}, \mathrm{l}, \mathrm{n}, \mathrm{o}$ & \\
\hline I & 0.85 & 3 & $-\mathrm{CH}_{3}$ & $\mathrm{t}$ & $\mathrm{p}$ & $-\mathrm{CH}_{2}-\mathrm{CH}_{3}$ \\
\hline
\end{tabular}

To establish how many types of carbon centres existed within the molecule, ${ }^{13} \mathrm{C}-\left\{{ }^{1} \mathrm{H}\right\} \mathrm{NMR}$ data (Figure S15) were examined. The data gave rise to $16 \mathrm{NMR}$ signals corresponding to sixteen different types of ${ }^{13} \mathrm{C}$ environments. Many of these showed similar chemical shifts (signals e-1). Additionally the intensities revealed that a number of carbon centres $(a, f, 1, m)$ were twice as abundant, resulting from symmetry within the structure. It was clear in particular from these data that the carbon signal (a) was due to two alkene carbons with identical chemical shifts, confirming the expectation that the structure would be roughly symmetrical about a central double bond, the symmetry of which would remain largely unaffected by remote tail groups.

$2 \mathrm{D}\left[{ }^{1} \mathrm{H},{ }^{13} \mathrm{C}\right] \mathrm{HSQC}-\mathrm{NMR}$ data (Figure S16) at both low and high resolution allowed the types of carbon to be distinguished for every centre, as well as editing the data to reveal protons that were not attached to carbon. As well as enabling the identification of $\mathrm{H} / \mathrm{C}$ correlations within each magnetic environment, these data also made it possible to confirm the number of protons associated with the lipid chain. These data also revealed that protons giving rise to Resonances B and D were not attached to carbon. By analogy with literature examples, it was clear that Resonance D was associated with water in DMSO and could therefore be discounted from the analysis. A summary of the ${ }^{13} \mathrm{C}-\mathrm{NMR}$ data are shown in Table 2. These data are summarized to provide a molecular formula of $\mathrm{C}_{20} \mathrm{H}_{40} \mathrm{O}$, yielding a molecular weight $(\mathrm{MW})=296$. Integration of the ${ }^{1} \mathrm{H}-\mathrm{NMR}$ spectrum is consistent with this formula and the number of protons "counted" using the $2 \mathrm{D}\left[{ }^{1} \mathrm{H},{ }^{13} \mathrm{C}\right] \mathrm{HSQC}-\mathrm{NMR}$ data. 
Table 2. Summary of ${ }^{13} \mathrm{C}-\mathrm{NMR}$ data for the lipid molecule as revealed by $1 \mathrm{D}^{13} \mathrm{C}-\left\{{ }^{1} \mathrm{H}\right\}$ and $2 \mathrm{D}\left[{ }^{1} \mathrm{H},{ }^{13} \mathrm{C}\right]$ HSQC-NMR data.

\begin{tabular}{ccccc}
\hline Label & $\delta(\mathbf{p p m})$ & No. of Carbons & Type & Link to ${ }^{\mathbf{1}} \mathbf{H}$ \\
\hline $\mathrm{a}$ & 130.09 & 2 & $\mathrm{CH}$ & $\mathrm{A}$ \\
$\mathrm{b}$ & 61.18 & 1 & $\mathrm{CH}$ & $\mathrm{C}$ \\
$\mathrm{c}$ & 33.03 & 1 & $\mathrm{CH}_{2}$ & $\mathrm{~F}$ \\
d & 31.76 & 1 & $\mathrm{CH}_{2}$ & $\mathrm{H}$ \\
e & 29.58 & 1 & $\mathrm{CH}_{2}$ & $\mathrm{H}$ \\
f & 29.56 & 2 & $\mathrm{CH}_{2}$ & $\mathrm{G}$ \\
g & 29.50 & 1 & $\mathrm{CH}_{2}$ & $\mathrm{H}$ \\
h & 29.45 & 1 & $\mathrm{CH}_{2}$ & $\mathrm{H}$ \\
i & 29.35 & 1 & $\mathrm{CH}_{2}$ & $\mathrm{H}$ \\
j & 29.31 & 1 & $\mathrm{CH}_{2}$ & $\mathrm{H}$ \\
k & 29.17 & 1 & $\mathrm{CH}_{2}$ & $\mathrm{H}$ \\
l & 29.06 & 2 & $\mathrm{CH}_{2}$ & $\mathrm{H}$ \\
m & 27.03 & 2 & $\mathrm{CH}_{2}$ & $\mathrm{E}$ \\
n & 25.99 & 1 & $\mathrm{CH}_{2}$ & $\mathrm{H}$ \\
o & 22.57 & 1 & $\mathrm{CH}_{2}$ & $\mathrm{H}$ \\
p & 14.40 & 1 & $\mathrm{CH}_{3}$ & $\mathrm{I}$ \\
\hline
\end{tabular}

Analysis of the remaining 2D $\left[{ }^{1} \mathrm{H},{ }^{1} \mathrm{H}\right]$ COSY and TOCSY and 2D $\left[{ }^{1} \mathrm{H},{ }^{13} \mathrm{C}\right] \mathrm{HSQC}$ and HMBC-NMR data (Figures S17-S19) is summarized in Table S7 and Table S8, respectively, in the Supplementary Materials. The triplet character of ${ }^{1} \mathrm{H}$ Resonance $\mathrm{B}$ and its correlation with Resonance $\mathrm{C}$ by COSY and TOCSY indicated that the hydroxyl group was a terminal $-\mathrm{OH}$ attached to a methylene, whose protons gave rise to Resonance C. The triplet character of proton Signal I similarly enabled the identity of this resonance to be associated with a terminal methyl group. Correlations were traced as far as possible from both the terminal positions and the alkene proton resonances (A) until these assignment pathways merged at Resonance H. $2 \mathrm{D}\left[{ }^{1} \mathrm{H},{ }^{13} \mathrm{C}\right] \mathrm{HMBC}-\mathrm{NMR}$ data were used to establish longer range $\mathrm{H} / \mathrm{C}$ correlations to reinforce the assignments, which remaining incomplete owing to the degeneracy at Signal H.

Following identification of coupling partners and piecing the structural evidence together, the proton and carbon assignments were allocated to a basic structure, as shown (Figure S20). It was not clear from the NMR data whether the double bond would be at the 9- or 10-position (shown in the 10-position in Figure S20). Neither was it clear from the data whether the double bond was of $E$ or $Z$ configuration. For this reason, simulations of the data were carried out based on both $E$ and $Z$ isomers of 9- and 10-eicosen-1-ol in order to throw some light on the conformation. Particular attention was paid to the appearance of proton Resonances A and E in these simulations, which would reflect directly on the conformation about the centralised double bond. The results of these simulations with their equivalent experimental counterparts are shown in Figure S21.

On balance, these data suggest a greater likelihood of the lipid existing in the (Z)-configuration, as shown in Figure S22. The position of the double bond is not revealed through these simulations or by experiment. Comparison with information provided directly through Beesen Co. Ltd., suppliers of the venom, suggests that the material and data are consistent with (Z)-eicos-9-en-1-ol.

\subsection{Identification of Minor Component in F-4}

Fraction F-4 was found to contain trace levels of an unidentified minor component with the $[\mathrm{M}-\mathrm{H}]^{-}$elemental composition of $\mathrm{C}_{43} \mathrm{H}_{70} \mathrm{O}_{11} \mathrm{P}(0.0783 \mathrm{ppm}$ mass tolerance) and MW 794.47. Collisional induced dissociation (CID) of the parental ion $(\mathrm{m} / \mathrm{z} 793.46)$ at a normalised collisional energy (NCE) of 35.0 produced two daughter ions, one with $m / z 493.2574\left(\mathrm{C}_{23} \mathrm{H}_{42} \mathrm{O}_{9} \mathrm{P}, 2.685 \mathrm{ppm}\right.$ mass tolerance, 40\%), possibly suggesting a loss of eicosapentenoic acid (MW 302), and the other with $m / z 643.3608\left(\mathrm{C}_{33} \mathrm{H}_{56} \mathrm{O}_{10} \mathrm{P}, 0.341 \mathrm{ppm}\right.$ mass tolerance, 60\%) (Figure S13). This elemental composition, though inconclusive, suggested the likelihood that the unknown impurity might be a phospholipid. 


\section{Discussion}

\subsection{Cytotoxicity}

The two fractions that were cytotoxic to U937 cells with $\mathrm{IC}_{50}$ values below $100 \mu \mathrm{g} / \mathrm{mL}$ contained melittin (F-3, IC $505.4 \mu \mathrm{g} / \mathrm{mL}$ ) and (Z)-9-eicosen-1-ol (F-4, IC $5068.8 \mu \mathrm{g} / \mathrm{mL})$. The latter also contained trace levels of an unidentified phospholipid. F-1 and F-2 were relatively non-toxic to U937 cells at the concentrations tested. The former contained mainly low MW amines, such as histamine, dopamine and noradrenaline, while the latter contained mainly $\mathrm{PLA}_{2}$, a major BV allergen [38,39]. Although one would have expected fraction F-2 to be cytotoxic due to its $\mathrm{PLA}_{2}$ content, it may be that the enzymatic activity reduced because of its separation from melittin (i.e., the venom PLA 2 and melittin act synergistically [40]) or as a result of loss of its $3 \mathrm{D}$ configuration during the fractionation. Fraction F-2 also contained variable amounts of the peptides apamin, MCD peptide and secapin, which were also detected in trace amounts in F-1.

Whereas the cytotoxicity of melittin is generally known in normal human and cancer cells [36,41], the biological activities of the organic fraction of BV are less well known. Melittin's cytotoxicity is thought to be due to membrane-disruption [42] and apoptotic actions mediated via mitochondrial and caspase activities [43]. During our experiments, the toxicity of F-4 (at $100 \mu \mathrm{g} / \mathrm{mL}$ ) was also observed in adherent normal human fibroblast (HS27) cells in which growth inhibition appeared to be associated with loss of cell attachment to the cell culture well plate (data not shown). Because of this, it had been anticipated that with suspended U937 cells, the F-4 fraction would have no such cytotoxic effect below $100 \mu \mathrm{g} / \mathrm{mL}$, since adherence was not a prerequisite for cell division and growth. Thus, the observed toxicity in U937 cells might suggest that F-4 acts within the cell, at least partially, rather than exclusively externally to it. Its amphiphilic structure would be consistent with an ability to penetrate and pass through cell membranes.

\subsection{Effect on Cytokine Release}

The enhancement of LPS-stimulated release of IL-1 $\beta$ in U937 cells was by far the most pronounced effect induced by all four BV fractions and crude BV, while the effects on TNF- $\alpha$ and IL-6 release were less marked, with variability between the fractions. The only significant effect on TNF- $\alpha$ release was due to F-4, while F-2 and F-3, which contained PLA 2 and melittin, respectively, were the most potent enhancers of IL- $1 \beta$ release by the cells following co-stimulation with LPS. Interestingly, F-4 showed anti-IL-6 effects. The IL-1 family of cytokines is closely linked to innate inflammatory and immune responses more than any other cytokine family, and IL- $1 \beta$ mediates auto-inflammatory diseases [44]. In the context of bees, the observed several-fold enhancement of IL-1 $\beta$ release by BV and all of its fractions is thus logical given the defensive function of the venom. Stimulation of IL-6 production is a key target for adjuvants due to its role in promoting B-lymphocyte differentiation into antibody-producing cells [45-47], T-cell proliferation [48] and development of cell-mediated cytotoxicity by CD8+ cells [49-51]. Thus, inhibition of IL-6 production by F-4 would suggest an immuno-suppressive action, but its concomitant stimulatory effect on TNF- $\alpha$, an important cytokine involved in the development of resistance to infection and cancer with roles in necrosis and apoptosis [52], suggests a more subtle mechanism.

Among the major components of F-1, histamine was reported to increase production of IL-6, expression of histamine receptors, expression of the kinases pp38, pERK and pJNK and induction of NF- $\mathrm{KB}$ in nasal fibroblasts when assayed at $200 \mu \mathrm{M}(\sim 22.2 \mu \mathrm{g} / \mathrm{mL})$ [14]. This concentration level was significantly higher than that present in the assay solutions of both the F-1 fraction and BV, which might explain their non-significant effects on IL-6. Bee venom PLA 2 , a major allergen and main component of F-2, and apamin have been shown to possess immune-inducing effects by activating T-cells [17] and promoting T-cell proliferation [13], respectively. Thus, the effects observed with F-2 on IL-1 $\beta$ and IL-6 production might be related to the effects of both $\mathrm{PLA}_{2}$ and apamin on the cells. 
Additionally, melittin, the sole component of F-3, has been reported to possess adjuvant properties by enhancing the absorption of intranasal tetanus and diphtheria toxoids [23]. This would support its effect on IL-1 $\beta$ observed in this study. However, these findings do not suggest that melittin could reduce the effect of LPS on cells, contrary to some previous studies [26,27]. The concentration used in the current study $(3 \mu \mathrm{g} / \mathrm{mL})$ was sub-lethal to the U937 cells, but at $10 \mu \mathrm{g} / \mathrm{mL}$, the concentration used in a previous study [27], melittin was found in the current study to be $100 \%$ cytotoxic. This was observed previously in dermal fibroblasts, mononuclear cells and fibroblast-like synoviocytes [30]. On the other hand, the study by Moon et al. [26] assayed both BV and melittin at $0.5-2.0 \mu \mathrm{g} / \mathrm{mL}$, levels that are all markedly lower than those employed in the current study. In the same study, LPS was assayed at $0.5 \mu \mathrm{g} / \mathrm{mL}$ compared to $1.0 \mu \mathrm{g} / \mathrm{mL}$ used in this study, and the cells were initially treated with BV or melittin for $1 \mathrm{~h}$ before treatment with LPS, rather than being simultaneously exposed [26]. Thus, the differences observed in these in vitro studies in relation to melittin's role in immuno-modulation might be related to the different experimental designs and/or concentrations of melittin and LPS used. In a previous study by Stuhlmeier (2007), neither BV nor melittin was found to inhibit IL-1 $\beta$-induced activation of NF- $\mathrm{kB}$. Instead, there were significant increases in the levels of the mRNA of several pro-inflammatory genes and COX-2 in synoviocytes, dermal fibroblasts and mononuclear cells [30]. The results obtained in our study corroborate these findings.

The main component of F-4, identified in this study as (Z)-9-eicosen-1-ol, resembled the lipid-soluble compound reported by Pickett et al. (1982) in A. mellifera venom and structurally elucidated as (Z)-11-eicosen-1-ol [53]. The latter was described as a natural pheromone, which acted synergistically with amyl acetate, another pheromone produced by the bees [53]. Schmidt et al. (1997) also reported the same long chain monounsaturated alcohol to be the main component of the oily fraction of Apis cerana venom [54], a species related to A. mellifera. The compound isolated in F-4 differs from that previously described with respect to the double bond position, which might be a means of conveying subtle differences in message recognition among the bees [55].

\section{Conclusions}

Inflammatory responses mediated by pro-inflammatory cytokines are a key component of protective immunity against many infections. This study shows that treatment of PMA-differentiated U937 cells with BV fractions significantly enhances the IL-1 $\beta$ cytokine release effect of LPS in these cells. However, neither BV nor its fractions could induce any significant cytokine release on their own. The largest synergistic effect was observed for IL- $1 \beta$ release, which was promoted by all fractions, while only the lipid fraction, F-4, enhanced TNF- $\alpha$ production in the cells co-stimulated with LPS. Although fraction F-4, identified to contain (Z)-9-eicosen-1-ol, was stimulatory for IL-1 $\beta$ and TNF- $\alpha$ release, it produced an inhibitory effect on IL-6 production. The commercial availability of this compound in larger amounts than can be isolated from the venom will allow us in future work to explore potential synergies between it and fractions F-1-F-3. In addition, it provides a lead compound for exploring the effects of other long chain alcohols, since they are accessible via reduction of the wide range of long chain fatty acids, that is commercially available. Taken together, these results do not support some studies in the literature that suggest that BV and melittin possess potential anti-inflammatory activity by antagonising LPS-stimulation of cytokine production. Instead, BV fractions synergise with LPS in the induction of the IL-1 $\beta$ cytokine release in U937 cells, and the lipophilic fraction has additional orthogonal effects on TNF- $\alpha$ and IL-6, whereby it induces the former and inhibits the latter. Overall, these effects provide valuable preliminary information to support further evaluation of purified BV as a potential source of natural adjuvants for some vaccines.

Supplementary Materials: The following are available online at www.mdpi.com/2076-393X/4/2/11/s1.

Acknowledgments: Jonans Tusiimire and Jennifer Wallace are funded by Beesen Co. and the Korea Institute for Advancement of Technology (KIAT) partnership with Strathclyde University. Nicola Woods is sponsored through a Biotechnology and Biological Sciences Research Council (BBSRC) Case studentship. 
Author Contributions: David G. Watson and Valerie A. Ferro conceived the project; Jonans Tusiimire, David G. Watson, Jennifer Wallace, John A. Parkinson and Mark J. Dufton purified and analysed the bee venom fractions; Jonans Tusiimire, Nicola Woods, Louise Young, Grainne Abbott, and Carol J. Clements performed the biology experiments and analysed their data; Jennifer Wallace, John A. Parkinson and Mark J. Dufton performed the NMR experiments and analysed their data; Jin Kyu Park and Jong Woon Jeon supplied the crude bee venom; Jonans Tusiimire, Jennifer Wallace, John A. Parkinson, Mark J. Dufton, Valerie A. Ferro and David G. Watson wrote and edited the manuscript.

Conflicts of Interest: The authors declare no conflict of interest.

\section{References}

1. Moreau, S.J. "It stings a bit but it cleans well": Venoms of Hymenoptera and their antimicrobial potential. J. Insect Physiol. 2013, 59, 186-204. [CrossRef] [PubMed]

2. Lee, J.D.; Park, H.J.; Chae, Y.; Lim, S. An overview of bee venom acupuncture in the treatment of arthritis. Evidence-Based Complement. Alternat. Med. 2005, 2, 79-84. [CrossRef] [PubMed]

3. Hider, R.C. Honeybee venom: A rich source of pharmacologically active peptides. Endeavour 1988, 12, 60-65. [CrossRef]

4. Rho, Y.H.; Woo, J.-H.; Choi, S.J.; Lee, Y.H.; Ji, J.D.; Song, G.G. A new onset of systemic lupus erythematosus developed after bee venom therapy. Korean J. Intern. Med. 2009, 24, 283-285. [CrossRef] [PubMed]

5. Zhou, J.; Zhao, J.; Zhang, S.; Shen, J.; Qi, Y.; Xue, X.; Li, Y.; Wu, L.; Zhang, J.; Chen, F.; Chen, L. Quantification of melittin and apamin in bee venom lyophilized powder from Apis mellifera by liquid chromatography-diode array detector-tandem mass spectrometry. Anal. Biochem. 2010, 404, 171-178. [CrossRef] [PubMed]

6. Chen, J.; Lariviere, W.R. The nociceptive and anti-nociceptive effects of bee venom injection and therapy: A double-edged sword. Prog. Neurobiol. 2010, 92, 151-183. [CrossRef] [PubMed]

7. Sciani, J.M.; Marques-Porto, R.; Lourenco Junior, A.; Orsi, R.D.O.; Ferreira Junior, R.S.; Barraviera, B.; Pimenta, D.C. Identification of a novel melittin isoform from Africanized Apis mellifera venom. Peptides 2010, 31, 1473-1479. [CrossRef] [PubMed]

8. Ferreira Junior, R.S.; Sciani, J.M.; Marques-Porto, R.; Lourenco Junior, A.; Orsi, R.D.O.; Barraviera, B.; Pimenta, D.C. Africanized honey bee (Apis mellifera) venom profiling: Seasonal variation of melittin and phospholipase $\mathrm{A}_{2}$ levels. Toxicon 2010, 56, 355-362. [CrossRef] [PubMed]

9. Baracchi, D.; Francese, S.; Turillazzi, S. Beyond the antipredatory defence: Honey bee venom function as a component of social immunity. Toxicon 2011, 58, 550-557. [CrossRef] [PubMed]

10. Van Vaerenbergh, M.; Cardoen, D.; Formesyn, E.M.; Brunain, M.; Van Driessche, G.; Blank, S.; Spillner, E.; Verleyen, P.; Wenseleers, T.; Schoofs, L.; et al. Extending the honey bee venome with the antimicrobial peptide apidaecin and a protein resembling wasp antigen 5. Insect Mol. Biol. 2013, 22, 199-210. [CrossRef] [PubMed]

11. Vick, J.A.; Shipman, W.H. Effects of whole bee venom and its fractions (apamin and melittin) on plasma cortisol levels in the dog. Toxicon 1972, 10, 377-380. [CrossRef]

12. Matysiak, J.; Schmelzer, C.E.H.; Neubert, R.H.H.; Kokot, Z.J. Characterization of honeybee venom by MALDI-TOF and nanoESI-QqTOF mass spectrometry. J. Pharm. Biomed. Anal. 2011, 54, 273-278. [CrossRef] [PubMed]

13. Regnier-Vigouroux, A.; el Ayeb, M.; Defendini, M.L.; Granier, C.; Pierres, M. Processing by accessory cells for presentation to murine $\mathrm{T}$ cells of apamin, a disulfide-bonded 18 amino acid peptide. J. Immunol. (Baltimore, Md.: 1950) 1988, 140, 1069-1075.

14. Park, I.H.; Um, J.Y.; Cho, J.S.; Lee, S.H.; Lee, H.M. Histamine promotes the release of interleukin-6 via the H1R/p38 and NF-kappaB pathways in nasal fibroblasts. Allergy, Asthma Immunol. Res. 2014, 6, 567-572. [CrossRef] [PubMed]

15. Buku, A.; Condie, B.; Price, J.; Mezei, M. [Ala12] MCD peptide: A lead peptide to inhibitors of immunoglobulin E binding to mast cell receptors1. J. Pept. Res. 2005, 66, 132-137. [CrossRef] [PubMed]

16. Buku, A. Mast cell degranulating (MCD) peptide: A prototypic peptide in allergy and inflammation. Peptides 1999, 20, 415-420. [CrossRef]

17. Bourgeois, E.A.; Subramaniam, S.; Cheng, T.Y.; De Jong, A.; Layre, E.; Ly, D.; Salimi, M.; Legaspi, A.; Modlin, R.L.; Salio, M.; et al. Bee venom processes human skin lipids for presentation by CD1a. J. Exp. Med. 2015, 212, 149-163. [CrossRef] [PubMed] 
18. Ichinose, M.; Miura, M.; Takahashi, T.; Yamauchi, H.; Kageyama, N.; Tomaki, M.; Endoh, N.; Sakurai, E.; Watanabe, T.; Shirato, K. Allergic airway response and potassium channels: Histamine release and airway inflammation. Methods Find. Exp. Clin. Pharmacol. 1995, 17 (Suppl. C), 36-39. [PubMed]

19. Lawrence, T. The Nuclear Factor NF-кB Pathway in Inflammation. Cold Spring Harbor Perspect. Biol. 2009, 1, a001651. [CrossRef] [PubMed]

20. Buku, A.; Price, J.A.; Mendlowitz, M.; Masur, S. Mast cell degranulating peptide binds to RBL-2H3 mast cell receptors and inhibits IgE binding. Peptides 2001, 22, 1993-1998. [CrossRef]

21. Shkenderov, S.; Koburova, K. Adolapin-A newly isolated analgetic and anti-inflammatory polypeptide from bee venom. Toxicon 1982, 20, 317-321. [CrossRef]

22. Koburova, K.L.; Michailova, S.G.; Shkenderov, S.V. Further investigation on the antiinflammatory properties of adolapin-Bee venom polypeptide. Acta Physiol. Pharmacol. Bulg. 1985, 11, 50-55. [PubMed]

23. Bramwell, V.W.; Somavarapu, S.; Outschoorn, I.; Alpar, H.O. Adjuvant action of melittin following intranasal immunisation with tetanus and diphtheria toxoids. J. Drug Target. 2003, 11, 525-530. [CrossRef] [PubMed]

24. Park, H.J.; Lee, S.H.; Son, D.J.; Oh, K.W.; Kim, K.H.; Song, H.S.; Kim, G.J.; Oh, G.T.; Yoon, D.Y.; Hong, J.T. Antiarthritic effect of bee venom: Inhibition of inflammation mediator generation by suppression of NF-kappaB through interaction with the p50 subunit. Arthritis Rheum. 2004, 50, 3504-3515. [CrossRef] [PubMed]

25. Park, H.J.; Son, D.J.; Lee, C.W.; Choi, M.S.; Lee, U.S.; Song, H.S.; Lee, J.M.; Hong, J.T. Melittin inhibits inflammatory target gene expression and mediator generation via interaction with IkappaB kinase. Biochem. Pharmacol. 2007, 73, 237-247. [CrossRef] [PubMed]

26. Srivastava, R.M.; Srivastava, S.; Singh, M.; Bajpai, V.K.; Ghosh, J.K. Consequences of alteration in leucine zipper sequence of melittin in its neutralization of lipopolysaccharide-induced proinflammatory response in macrophage cells and interaction with lipopolysaccharide. J. Biol. Chem. 2012, 287, 1980-1995. [CrossRef] [PubMed]

27. Moon, D.O.; Park, S.Y.; Lee, K.J.; Heo, M.S.; Kim, K.C.; Kim, M.O.; Lee, J.D.; Choi, Y.H.; Kim, G.Y. Bee venom and melittin reduce proinflammatory mediators in lipopolysaccharide-stimulated BV2 microglia. Int. Immunopharmacol. 2007, 7, 1092-1101. [CrossRef] [PubMed]

28. Jang, H.S.; Kim, S.K.; Han, J.B.; Ahn, H.J.; Bae, H.; Min, B.I. Effects of bee venom on the pro-inflammatory responses in RAW264.7 macrophage cell line. J. Ethnopharmacol. 2005, 99, 157-160. [CrossRef] [PubMed]

29. Vick, J.A.; Mehlman, B.; Brooks, R.; Phillips, S.J.; Shipman, W. Effect of the bee venom and melittin on plasma cortisol in the unanesthetized monkey. Toxicon 1972, 10, 581-586. [CrossRef]

30. Stuhlmeier, K.M. Apis mellifera venom and melittin block neither NF-kappa B-p50-DNA interactions nor the activation of NF-kappa B, instead they activate the transcription of proinflammatory genes and the release of reactive oxygen intermediates. J. Immunol. (Baltimore, Md.: 1950) 2007, 179, 655-664. [CrossRef]

31. Sundstrom, C.; Nilsson, K. Establishment and characterization of a human histiocytic lymphoma cell line (U-937). Int. J. Cancer 1976, 17, 565-577. [CrossRef] [PubMed]

32. Minta, J.O.; Pambrun, L. In vitro induction of cytologic and functional differentiation of the immature human monocytelike cell line U-937 with phorbol myristate acetate. Am. J. Pathol. 1985, 119, 111-126. [PubMed]

33. Passmore, J.S.; Lukey, P.T.; Ress, S.R. The human macrophage cell line U937 as an in vitro model for selective evaluation of mycobacterial antigen-specific cytotoxic T-cell function. Immunology 2001, 102, 146-156. [CrossRef] [PubMed]

34. Verhoeckx, K.C.; Bijlsma, S.; de Groene, E.M.; Witkamp, R.F.; van der Greef, J.; Rodenburg, R.J. A combination of proteomics, principal component analysis and transcriptomics is a powerful tool for the identification of biomarkers for macrophage maturation in the U937 cell line. Proteomics 2004, 4, 1014-1028. [CrossRef] [PubMed]

35. Tusiimire, J.; Wallace, J.; Dufton, M.; Parkinson, J.; Clements, C.J.; Young, L.; Park, J.K.; Jeon, J.W.; Watson, D.G. An LCMS method for the assay of melittin in cosmetic formulations containing bee venom. Anal. Bioanal. Chem. 2015, 407, 3627-3635. [CrossRef] [PubMed]

36. Gajski, G.; Garaj-Vrhovac, V. Melittin: A lytic peptide with anticancer properties. Environ. Toxicol. Pharmacol. 2013, 36, 697-705. [CrossRef] [PubMed]

37. Otte, A.; Mandel, K.; Reinstrom, G.; Hass, R. Abolished adherence alters signaling pathways in phorbol ester-induced human U937 cells. Cell Commun. Signal. 2011, 9. [CrossRef] [PubMed] 
38. Dhillon, M.; Roberts, C.; Nunn, T.; Kuo, M. Mapping human T cell epitopes on phospholipase $\mathrm{A}_{2}$ : The major bee-venom allergen. J. Allergy Clin. Immunol. 1992, 90, 42-51. [CrossRef]

39. Ameratunga, R.V.; Hawkins, R.; Prestidge, R.; Marbrook, J. A high efficiency method for purification and assay of bee venom phospholipase A2. Pathology 1995, 27, 157-160. [CrossRef] [PubMed]

40. Habermann, E. Bee and wasp venoms. Science (New York, N.Y.) 1972, 177, 314-322. [CrossRef]

41. Son, D.J.; Lee, J.W.; Lee, Y.H.; Song, H.S.; Lee, C.K.; Hong, J.T. Therapeutic application of anti-arthritis, pain-releasing, and anti-cancer effects of bee venom and its constituent compounds. Pharmacol. Ther. 2007, 115, 246-270. [CrossRef] [PubMed]

42. Lee, M.T.; Sun, T.L.; Hung, W.C.; Huang, H.W. Process of inducing pores in membranes by melittin. Proc. Natl. Acad. Sci. USA 2013, 110, 14243-14248. [CrossRef] [PubMed]

43. Lee, J.; Lee, D.G. Melittin triggers apoptosis in Candida albicans through the reactive oxygen species-mediated mitochondria/caspase-dependent pathway. FEMS Microbiol. Lett. 2014, 355, 36-42. [CrossRef] [PubMed]

44. Dinarello, C.A. Overview of the interleukin-1 family of ligands and receptors. Semin. Immunol. 2013, 25, 389-393. [CrossRef] [PubMed]

45. Bertolini, J.N.; Benson, E.M. The role of human interleukin-6 in B-cell isotype regulation and differentiation. Cell. Immunol. 1990, 125, 197-209. [CrossRef]

46. Beagley, K.W.; Eldridge, J.H.; Lee, F.; Kiyono, H.; Everson, M.P.; Koopman, W.J.; Hirano, T.; Kishimoto, T.; McGhee, J.R. Interleukins and IgA synthesis: Human and murine interleukin 6 induce high rate IgA secretion in IgA-committed B cells. J. Exp. Med. 1989, 169, 2133-2148. [CrossRef] [PubMed]

47. Hilbert, D.M.; Cancro, M.P.; Scherle, P.A.; Nordan, R.P.; Van Snick, J.; Gerhard, W.; Rudikoff, S. T cell derived IL-6 is differentially required for antigen-specific antibody secretion by primary and secondary B cells. J. Immunol. (Baltimore, Md.: 1950) 1989, 143, 4019-4024.

48. Tosato, G.; Pike, S.E. Interferon-beta 2/interleukin 6 is a co-stimulant for human T lymphocytes. J. Immunol. (Baltimore, Md.: 1950) 1988, 141, 1556-1562.

49. Van Snick, J.; Vink, A.; Uyttenhove, C.; Houssiau, F.; Coulie, P. B and T cell responses induced by interleukin-6. Curr. Top. Microbiol. Immunol. 1988, 141, 181-184. [PubMed]

50. Okada, M.; Kitahara, M.; Kishimoto, S.; Matsuda, T.; Hirano, T.; Kishimoto, T. IL-6/BSF-2 functions as a killer helper factor in the in vitro induction of cytotoxic T cells. J. Immunol. (Baltimore, Md.: 1950) 1988, 141, 1543-1549.

51. Houssiau, F.; Van Snick, J. IL6 and the T-cell response. Res. Immunol. 1992, 143, 740-743. [CrossRef]

52. Idriss, H.T.; Naismith, J.H. TNF alpha and the TNF receptor superfamily: Structure-function relationship(s). Microsc. Res. Techn. 2000, 50, 184-195. [CrossRef]

53. Pickett, J.A.; Williams, I.; Martin, A.P. (Z)-11-eicosen-1-ol, an important new pheromonal component from the sting of the honey bee, Apis mellifera L. (Hymenoptera, Apidae.). J. Chem. Ecol. 1982, 8, 163-175. [CrossRef] [PubMed]

54. Schmidt, J.O.; Morgan, E.D.; Oldham, N.J.; Do Nascimento, R.R.; Dani, F.R. (Z)-11-Eicosen-1-ol, a major component of Apis cerana venom. J. Chem. Ecol. 1997, 23, 1929-1939. [CrossRef]

55. Boch, R.; Morse, R.A. Discrimination of familiar and foreign queens by honey bee swarms. Ann. Entomol. Soc. Am. 1974, 67, 709-711. [CrossRef]

(C) 2016 by the authors; licensee MDPI, Basel, Switzerland. This article is an open access article distributed under the terms and conditions of the Creative Commons Attribution (CC-BY) license (http://creativecommons.org/licenses/by/4.0/). 